\title{
Slicing the salt content of bread in Ireland: a review of reformulation since 2003
}

\author{
O. Feehan ${ }^{1}$, K. McElroy ${ }^{1}$, M. Clements ${ }^{1}$, B.E. Cronin ${ }^{1}$, B. Griffin ${ }^{1}$, F.E. Douglas ${ }^{1}$, \\ O.C. Lyons ${ }^{1,2}$, M.A.T. Flynn ${ }^{1,2}$ and K. McDonald ${ }^{1}$ \\ ${ }^{1}$ Food Safety Authority of Ireland, Dublin 1, Republic of Ireland and ${ }^{2}$ Northern Ireland Centre for Food and Health, \\ University of Ulster, Coleraine, BT52 1SA, UK
}

For prevention of cardiovascular disease daily salt intakes should be restricted ${ }^{(1)}$ and should not exceed 6 g/day ${ }^{(2)}$. However, in 2001 adults in Ireland were estimated to consume $10 \mathrm{~g}$ /day of salt with over a quarter coming from bread ${ }^{(3)}$. In 2003 , the Food Safety Authority of Ireland (FSAI) initiated with the food industry a programme to reduce the salt content of processed food ${ }^{(2)}$. Bread is a staple food in Ireland, with wholemeal being actively promoted for a healthy diet ${ }^{(4)}$. This study evaluates the impact of the salt reduction programme by assessing the level of salt in bread since 2003. Breads commonly available in Ireland were identified through market research. These were categorised into five different bread types; white, brown, wholemeal/wholegrain, soda and speciality. Samples ( $n$ 694) were collected from each category at five different time points between 2003 and 2015 and analysed at the Public Analyst's Laboratory Galway. The salt content of the breads (g per $100 \mathrm{~g}$ ) was assessed using flame photometry. The 2013 and 2015 (2010/2011 for soda bread) salt content findings were compared with those of 2003. As shown in the table, the salt content has significantly decreased (up to $32 \%$ ) in white, brown, wholemeal/wholegrain, soda and speciality breads since 2003 . The salt content of wholemeal/ wholegrain breads decreased up to 2013, whereas white and speciality bread decreased until 2010/2011 and remained stable onwards. However the salt content of brown breads having reduced initially (in 2005/ 2006) has tended to fluctuate since.

\begin{tabular}{|c|c|c|c|c|c|c|c|c|c|c|}
\hline & \multicolumn{2}{|r|}{2003} & \multicolumn{2}{|r|}{$2005 / 2006$} & \multicolumn{2}{|r|}{$2010 / 2011$} & \multicolumn{2}{|r|}{2013} & \multicolumn{2}{|r|}{2015} \\
\hline & $n$ & Salt $(\mathrm{g})$ per $100 \mathrm{~g}$ & $n$ & Salt $(\mathrm{g})$ per $100 \mathrm{~g}$ & $n$ & Salt $(\mathrm{g})$ per $100 \mathrm{~g}$ & $n$ & Salt $(\mathrm{g})$ per $100 \mathrm{~g}$ & $n$ & Salt $(\mathrm{g})$ per $100 \mathrm{~g}$ \\
\hline White & 22 & $\begin{array}{c}1.32 \\
(1 \cdot 17-1 \cdot 78)\end{array}$ & 22 & $\begin{array}{c}1.22 \\
(0.86-1.84)\end{array}$ & 60 & $\begin{array}{c}1.12 \\
(0.66-1.63)\end{array}$ & 36 & $\begin{array}{c}1.12^{*} \\
(0.86-1.63)\end{array}$ & 39 & $\begin{array}{c}1.12^{*} \\
(0.76-1.57)\end{array}$ \\
\hline Brown & 15 & $\begin{array}{c}1.41 \\
(1.02-2 \cdot 4)\end{array}$ & 23 & $\begin{array}{c}1 \cdot 15 \\
(0.86-1 \cdot 33)\end{array}$ & 24 & $\begin{array}{c}1.23 \\
(0.89-1.60)\end{array}$ & 36 & $\begin{array}{c}1.07^{*} \\
(0.89-1.42)\end{array}$ & 18 & $\begin{array}{c}1.30^{*} \\
(1.02-1.52)\end{array}$ \\
\hline Wholemeal/ Wholegrain & 24 & $\begin{array}{c}1.48 \\
(0.43-2 \cdot 39)\end{array}$ & 27 & $\begin{array}{c}1.11 \\
(0.59-1.43)\end{array}$ & 55 & $\begin{array}{c}1.17 \\
(0.64-1.98)\end{array}$ & 42 & $\begin{array}{c}1.02 * \\
(0.76-1.52)\end{array}$ & 28 & $\begin{array}{c}1.09 * \\
(0.81-1.42)\end{array}$ \\
\hline Soda & 13 & $\begin{array}{c}2 \cdot 22 \\
(1 \cdot 46-3 \cdot 12)\end{array}$ & 40 & $\begin{array}{c}1.96 \\
(1.22-2 \cdot 50)\end{array}$ & 18 & $\begin{array}{c}1.85^{*} \\
(0.76-2.03)\end{array}$ & 0 & No data & 0 & No data \\
\hline Speciality & 26 & $\begin{array}{c}1 \cdot 43 \\
(0 \cdot 81-2 \cdot 27)\end{array}$ & 31 & $\begin{array}{c}1 \cdot 16 \\
(0.71-1 \cdot 86)\end{array}$ & 29 & $\begin{array}{c}0.99 \\
(0.91-1.40)\end{array}$ & 9 & $\begin{array}{c}0.99 * \\
(0 \cdot 86-1 \cdot 14)\end{array}$ & 57 & $\begin{array}{c}0.97 * \\
(0 \cdot 61-1 \cdot 88)\end{array}$ \\
\hline
\end{tabular}

Values are median (range). *Median value significantly different from 2003, $P<0.05$ obtained by Mann -Whitney U.

Since 2003 reformulation has significantly lowered the salt content of bread in Ireland. In 2011 it was estimated that salt intakes among adults in Ireland fell to $7.4 \mathrm{~g} /$ day with $22 \%$ coming from bread ${ }^{(5)}$. Periodic monitoring is required to ensure reduced salt levels in bread are maintained.

1. Strazzullo P, D'Elia L, Kandala NB et al. (2009) BMJ 339;b4567.

2. Food Safety Authority of Ireland (2005). Salt and Health: Review of the Scientific Evidence and Recommendations for Public Policy in Ireland. Dublin: FSAI.

3. North/South Ireland Food Consumption Survey (2001).

4. Flynn MAT, O'Brien CM, Ross V et al. (2012) Public Health Nutr 15, 527-37.

5. 5 National Adult Nutrition Survey (2011). 